\title{
BERPIKIR REFLEKTIF DALAM PEMECAHAN MASALAH PECAHAN DITINJAU DARI KEMAMPUAN AWAL TINGGI DAN GENDER
}

\author{
Fina Tri Wahyuni ${ }^{1}$ \\ Arnetta Thalia Arthamevia ${ }^{2}$ \\ Danang Haryo ${ }^{3}$ \\ ${ }^{123}$ Institut Agama Islam Negeri Kudus \\ ${ }^{1}$ finatriwahyuni26@gmail.com \\ 2arnettathalia6@gmail.com \\ 3 haryodanang68@gmail.com
}

\begin{abstract}
Abstrak: Penelitian bertujuan mendeskripsikan karakteristik berpikir reflektif siswa SMP laki-laki dan perempuan berkemampuan awal tinggi dalam pemecahan masalah pecahan. Jenis penelitian merupakan penelitian kualitatif. Pengambilan sampel dengan teknik purposive sampling dan snowball sampling. Subjek dalam penelitian sebanyak tiga subjek, yaitu satu siswa laki-laki dan dua siswa perempuan berkemampuan awal tinggi. Teknik pengumpulan data menggunakan wawancara berbasais tugas. Validitas data menggunakan triangulasi waktu. Hasil penelitian menunjukkan bahwa: (1) Siswa laki-laki berkemampuan awal tinggi: (a) tahap merencanakan penyelesaian, mengidentifikasi konsep pada masalah, menjelaskan apa yang telah dilakukan; (b) tahap melaksanakan rencana penyelesaian, menyadari kesalahan dan memperbaikinya, memeriksa kebenaran suatu argumen, menggunakan pengetahuan dari dalam diri, mengaitkan informasi yang telah diketahui, mengkomunikasikan ide dengan simbol bukan dengan gambar atau objek langsung; (c) tahap memeriksa kembali, menarik kesimpulan kekonteks masalah, menjelaskan apa yang telah dilakukan. (2) Siswa perempuan berkemampuan awal tinggi: (a) tahap memahami masalah, menyebutkan informasi pada masalah, menjelaskan apa yang telah dilakukan; (b) tahap merencanakan penyelesaian, mengidentifikasi konsep pada masalah, menjelaskan apa yang telah dilakukan; (c) tahap melaksanakan rencana penyelesaian, menyadari kesalahan dan memperbaikinya, memeriksa kebenaran suatu argumen.
\end{abstract}

Kata Kunci: Karakteristik berpikir reflektif, pemecahan masalah, kemampuan awal tinggi, gender.

\begin{abstract}
The aims of this research was to describe the characteristics of reflective thinking the students of male and female State Junior Secondary School who have the high abilities in solving fractional problems. This research used qualitative research. Sampling was done by a purposive sampling dan snowball sampling. There are three subjects in this research: male student and two female students who have the high abilities. The date of research were gathered through task based in depth interview. The data was validated using a time triangulation test. The results of research were the characteristics of reflective thinking of the students as follows: (1) the male with high abilities: (a) in the problem-solving planning phase, identify the concept of the problems and to explain what has been done; (b) in the implementation of problem-solving plan phase, to realize the mistakes and to fix them, to examine the truth of an argument, to employ the internal knowledge, to relate the information that they have known, and to communicate ideas with symbols instead of pictures or direct objects; $(c)$ in the reexamination phase, to draw conclusions to return the answers back into the contexts and to explain what has been done. (2) the female with high abilities: (a) in the problem understanding phase, mention information of the problems and to explain what has been done; (b) in the problem-solving planning phase, identify the concept of the problems and to explain what has been done; $(c)$ in the implementation of problem-solving plan phase, to realize the mistakes and to fix them, to examine the truth of an argument.
\end{abstract}

Keywords: Characteristics of reflective thinking, problem solving, high initial ability in Mathematics, and gender. 


\section{PENDAHULUAN}

Pembelajaran matematika memiliki peranan yang penting dalam dunia pendidikan. Setiap jenjang pendidikan mulai dari sekolah dasar sampai perguruan tinggi membelajarkan matematika. Pembelajaran matematika tidak akan terlepas dari pemecahan masalah. Oleh karena itu, diharapkan pembelajaran matematika di sekolah tidak hanya menekankan pada pemberian rumus-rumus melainkan juga membelajarkan siswa untuk dapat menyelesaikan berbagai masalah matematis. Salah satu berpikir matematis yang mendukung kemampuan pemecahan masalah siswa dalam pembelajaran matematika adalah berpikir reflektif (reflective thinking). Hal ini terkait dengan kebutuhan siswa untuk memecahkan masalah yang dihadapinya dalam kehidupan sehari-hari.

Berpikir reflektif merupakan berpikir yang bermakna didasarkan pada alasan dan tujuan. Jenis berpikir ini melibatkan pemecahan masalah, perumusan kesimpulan, memperhitungkan apa saja yang akan dilakukan, dan membuat keputusan-keputusan di saat seseorang menggunakan ketrampilan yang bermakna dan efektif untuk konteks tertentu dan jenis dari tugas berpikir. Berpikir reflektif dapat mengembangkan ketrampilan-ketrampilan berpikir tingkat tinggi melalui dorongan untuk menghubungkan pengetahuan baru pada pemahaman mereka yang terdahulu, berpikir dalam terminologi abstrak dan konkrit, menerapkan strategi spesifik untuk tugas-tugas baru, dan memahami proses berpikir mereka sendiri dan belajar strategi.

Menurut Gurol (2011) berpikir reflektif sebagai proses kegiatan terarah dan tepat dimana individu dapat menyadari, menganalisis, mengevaluasi, dan memotivasi dalam proses belajarnya sendiri. Dengan demikian, berpikir reflektif guru bertujuan untuk mencapai target belajar dan menghasilkan pendekatan pembelajaran baru yang berdampak langsung pada proses belajar. Selanjutnya dijelaskan bahwa proses pemikiran reflektif dapat mengurangi faktor kesalahan saat siswa memecahkan masalah yang dihadapi. Sedangkan menurut Sezer (dalam Choy dan Oo, 2012) berpikir reflektif merupakan kesadaran tentang apa yang diketahui dan dibutuhkan, hal ini sangat penting untuk menjembatani kesenjangan situasi belajar. Selain itu, berpikir reflektif berperan sebagai sarana untuk mendorong pemikiran selama situasi pemecahan masalah, karena memberikan kesempatan untuk belajar dan memikirkan strategi terbaik untuk mencapai tujuan pembelajaran.

Seorang guru perlu mengetahui karakteristik proses berpikir reflektif siswa. Hal ini dapat membantu guru dalam melacak kesalahan yang dilakukan oleh siswa. Kesalahan yang teramati dapat dijadikan sumber informasi dalam perbaikan kualitas pembelajaran. Selain itu, juga dapat membantu guru dalam melatih proses berpikir siswa supaya lebih terarah dan berkembang sesuai struktur kognitif dan afektifnya. Hal ini sejalan dengan yang dikemukakan oleh Piaget (dalam Suparno, 2010: 39) bahwa pembelajaran matematika selayaknya disesuaikan dengan perkembangan struktur kognitif dan afektif siswa. Menurut Kember (dalam Mahasneh, 2013: 52) mengungkapkan bahwa berpikir reflektif dapat 
digolongkan ke dalam 4 tahap yaitu: (a) tindakan biasa (habitual action), (b) pemahaman (understanding), (c) refleksi (reflection), dan (d) berpikir kritis (critical thinking).

Dewey (dalam Song, et al. 2005) menyatakan bahwa berpikir reflektif adalah "Active, persitent, and careful consideration of abelief or suposed form of knowledge on the grounds that reflective thinking suports the belief or knowledge and the further conclusions one can draw about it". Dengan kata lain berpikir reflektif adalah aktif terus menerus, gigih, dan mempertimbangkan dengan seksama tentang segala sesuatu yang dipercaya kebenarannya atau format yang diharapkan tentang pengetahuan apabila dipandang dari sudut pandang yang mendukungnya dan menuju pada suatu kesimpulan.

Namun, berdasarkan hasil observasi yang telah dilakukan di SMP N 3 Polanharjo Klaten menunjukkan bahwa selama ini kemampuan berpikir reflektif belum menjadi bagian tujuan pembelajaran matematika yang penting oleh guru. Dalam pembelajaran matematika di SMP, guru jarang menggembangkan kemampuan berpikir reflektif. Hal tersebut serupa dengan pernyataan yang dikemukakan Moss (2010) bahwa kegiatan berpikir reflektif sering tidak dilakukan secara efektif dan sulit dibiasakan pada siswa. Jozua (2010) juga menyatakan bahwa berpikir reflektif masih jarang dibiasakan oleh guru dan dikembangkan pada siswa sekolah menengah. Kondisi pembelajaran seperti itu merupakan salah satu alasan rendahnya kemampuan berpikir reflektif siswa. Hal ini didukung oleh Hepsi Nindiasari (2010) dalam studi pendahuluannya memperoleh beberapa temuan salah satunya yaitu lebih dari $60 \%$ siswa sekolah menengah belum mampu menyelesaikan tugas-tugas berpikir reflektif matematis, misalnya tugas menginterpretasi, mengaitkan, dan mengevaluasi. Oleh karena itu diperlukan upaya guru untuk melatih kemampuan berpikir reflektif siswa khususnya dalam memecahkan masalah matematika.

Kemampuan berpikir reflektif sering kali dikaitkan dengan aktivitas pemecahan masalah. Menurut Krulik dan Rudnik (dalam Dindyal, 2005) menggambarkan suatu masalah sebagai suatu situasi yang memerlukan pemecahan dimana seseorang tidak melihat suatu alat atau metode yang jelas dalam memperoleh pemecahan dari masalah yang bersangkutan. Jozua Sabandar (dalam Muhammad Irfan, 2013) mengungkapkan bahwa untuk mengembangkan kemampuan berpikir reflektif siswa, maka siswa harus dilibatkan dalam suatu pemecahan masalah. Pemecahan masalah itu sendiri menurut Santrock (2010) merupakan suatu proses kognitif dalam mencari solusi atau cara penyelesaian yang tepat untuk mencapai suatu tujuan. Langkah-langkah pemecahan masalah yang digunakan dalam penelitian ini adalah langkah-langkah pemecahan masalah oleh Polya (Erman Suherman, 2003: 91) yaitu ketika siswa memahami masalah, merencanakan penyelesaian masalah, melaksanakan rencana penyelesaian masalah, dan memeriksa kembali.

Selain perlu mengetahui karakteristik proses berpikir reflektif, seorang guru juga perlu memperhatikan kemampuan awal matematika siswa dalam pembelajaran. Hal tersebut memungkinkan terjadinya perbedaan penerimaan materi masing-masing siswa yang pada dasarnya memiliki kemampuan awal berbeda satu sama lain. Sehingga berakibat pula pada perbedaan kemampuan berpikir mereka. Kemampuan awal siswa akan 
berpengaruh pada pemahaman siswa pada materi selanjutnya. Hal ini sejalan dengan pendapat Pentatito $(2008,28)$ yang menyatakan bahwa kemampuan awal merupakan kemampuan yang telah melekat pada seseorang dan yang terkait dengan hal baru yang akan dipelajari selanjutnya.

Kemampuan awal merupakan pondasi dan dasar pijakan untuk pembentukan konsep baru dalam pembelajaran. Suatu proses pembelajaran dapat dikatakan bermakna jika seorang siswa telah dapat mengaitkan konsep-konsep yang ada dalam benaknya dengan baik. Kemampuan awal matematika merupakan salah satu faktor yang menentukan sukses atau gagalnya seorang siswa dalam belajar. Siswa diarahkan belajar melalui suatu proses yang berangsur-angsur secara bertahap dari konsep yang sederhana hingga pada pengertian yang lebih kompleks. Sampai akhirnya siswa tersebut mengerti, memahami, menguasai dan mampu mengaplikasikannya dalam pemecahan masalah kehidupan seharihari. Arends $(2008,268)$ menjelaskan bahwa kemampuan awal matematika dapat dibedakan dalam tiga kategori yaitu tinggi, sedang, dan rendah.

Siswa terdiri dari dua jenis kelamin (gender) yaitu laki-laki dan perempuan. Dari perbedaan gender tersebut, ada kemungkinan bahwa proses berpikir reflektif dalam memecahkan masalah matematika akan berbeda. Menurut (Santrock, 2007: 99), anak lakilaki sedikit lebih baik dibanding dengan anak perempuan dalam matematika dan sains. Secara umum siswa laki-laki sama dengan siswa perempuan, akan tetapi siswa laki-laki memiliki daya abstraksi yang lebih baik dari siswa perempuan sehingga memungkinkan siswa laki-laki lebih baik dari pada siswa perempuan dalam bidang matematika, karena pada umumnya matematika berkenaan dengan pengertian yang abstrak. Zhu (2007: 192) mengemukakan bahwa ada banyak faktor yang membuat adanya perbedaan gender dalam proses pemecahan masalah matematika, salah satunya adalah cognitive abilities. Zhu (2007: 199) mengemukakan bahwa terdapat perbedaan antara laki-laki dengan perempuan dalam pemecahan masalah matematika di Sekolah Menengah Pertama (SMP) sampai perguruan tinggi dengan masalah yang bervariasi.

Jean Piaget (dalam Syamsul Yusuf, 2009) menjelaskan bahwa perkembangan kognitif remaja terjadi pada anak SMP idealnya sudah memiliki pola pikir sendiri dalam usaha memecahkan masalah-masalah yang kompleks dan abstrak. Para remaja tidak lagi menerima informasi apa adanya, tetapi mereka akan memproses informasi itu serta mengadaptasikannya dengan pemikiran mereka sendiri. Mereka juga mampu mengintegrasikan pengalaman masa lalu dan sekarang untuk ditransformasikan menjadi konklusi, prediksi, dan rencana untuk masa depan. Dengan kemampuan operasional formal ini, para remaja mampu mengadaptasikan diri dengan lingkungan sekitar mereka.

Berdasarkan karakteristik siswa SMP tersebut, seharusnya siswa SMP sudah mampu melakukan proses berpikir reflektif dengan baik. Hal ini didukung oleh pendapat Hmelo \& Ferrari (1997) yang menyatakan bahwa siswa SMP sudah mampu melakukan ketrampilan-ketrampilan berpikir tingkat tinggi melalui dorongan mereka untuk: a) menghubungkan pengetahuan baru kepada pemahaman mereka yang terdahulu, b) berpikir 
dalam terminologi abstrak dan kongkrit, c) menerapkan strategi spesifik untuk tugas-tugas baru, dan d) memahami proses berpikir mereka sendiri dan belajar strategi.

Materi pecahan masih dirasa sulit untuk sebagian siswa. McGuire (dalam Hery Suharna, 2012) menyatakan bahwa siswa memiliki kesulitan belajar pecahan dalam matematika. Hal ini disebabkan karena siswa tidak memiliki pemahaman tentang materi pecahan. Banyak siswa yang ceroboh saat mengerjakan seperti kurang teliti, terburu-buru tanpa mengoreksi kembali pekerjaannya, sehingga siswa tidak mengetahui jika pekerjaannya masih salah atau malah belum dikerjakan.

Masalah penguasaan materi soal matematika tersebut berlaku umum di seluruh Indonesia, termasuk di Kabupaten Klaten, Jawa Tengah. Berdasarkan data hasil Ujian Nasional SMP tahun pelajaran 2013/2014, persentase penguasaan materi soal matematika pada kemampuan menyelesaikan soal cerita terkait konsep operasi tambah, kurang, kali, dan bagi pada bilangan pecahan yaitu pada tingkat rayon $41,29 \%$, sedangkan pada tingkat propinsi 46,52\%, dan pada tingkat nasional 46,69\%. Persentase penguasaan materi soal matematika pada kemampuan menentukan hasil penarikan akar dari bilangan bulat berpangkat bilangan pecahan yaitu pada tingkat rayon 55,43\%, sedangkan pada tingkat propinsi 63,34\%, dan pada tingkat nasional mencapai 68,80\%. Persentase penguasaan materi soal matematika pada kemampuan menyelesaikan soal cerita berkaitan dengan perbandingan berbalik nilai yaitu pada tingkat rayon 46,41\%, sedangkan pada tingkat propinsi 53,66\%, dan pada tingkat nasional mencapai 60,18\% (Tim BSNP, 2014).

Berdasarkan data di atas, daya serap pada materi Pecahan khususnya pada indikator menyelesaikan soal cerita terkait konsep operasi tambah, kurang, kali, dan bagi bilangan pecahan masih rendah dari tingkat Provinsi maupun Nasional. Hasil Ujian Nasional tersebut menggambarkan prestasi belajar siswa di Kabupaten Klaten untuk bidang studi matematika masih rendah dan belum merata. Padahal kaidah pecahan banyak digunakan ketika siswa memecahkan masalah-masalah keseharian mereka. Rendahnya daya serap dan banyaknya kesalahan dalam pemecahan masalah pecahan diduga karena kekurangmampuan siswa dalam berpikir reflektif

Berdasarkan latar belakang yang telah disampaikan, maka dapat dirumuskan masalah penelitian yaitu bagaimana karakteristik berpikir reflektif siswa SMP laki-laki dan perempuan berkemampuan awal tinggi dalam pemecahan masalah pecahan?.

\section{METODE PENELITIAN}

Penelitian dilaksanakan di SMP Negeri 3 Polanharjo Kabupaten Klaten dengan subjek penelitian siswa kelas VII C semester ganjil tahun ajaran 2014/2015. Penelitian ini termasuk ke dalam jenis penelitian kualitatif studi kasus terpancang. Menurut H. B. Sutopo (2006: 137-139), studi kasus mengarah pada pendeskripsian secara rinci dan mendalam mengenai suatu kondisi yang sebenarnya terjadi di lapangan. Pada penelitian yang sifatnya terpancang memiliki batasan yang tegas dan jelas karena memiliki fokus penelitian yang sudah terarah. Teknik pemilihan subjek menggunakan teknik purposive sampling. Teknik 
purposive sampling yaitu suatu cara pengambilan informan sumber data dengan pertimbangan tertentu (Sugiyono, 2012: 216). Pertimbangan tertentu ini merupakan kriteria pemilihan subjek yaitu: (1) telah mendapatkan pembelajaran mengenai operasi hitung bilangan pecahan, (2) siswa yang dapat mengkomunikasikan idenya dengan jelas baik secara tertulis maupun lisan, dan (3) mempunyai potensi memenuhi proses berpikir reflektif yang dikonstruksikan, yaitu memiliki kemampuan awal matematika tinggi.

Kemampuan awal matematika siswa dalam penelitian ini diperoleh dari nilai ulangan harian materi pecahan kelas VII C SMP Negeri 3 Polanharjo Klaten tahun ajaran 2014/2015, yang dibedakan dalam tiga kategori yaitu tinggi, sedang, dan rendah berdasarkan rumus acuan norma yang dapat dilihat pada Tabel berikut.:

Tabel Rumus Acuan Norma

\begin{tabular}{|c|c|}
\hline Skor & Kelompok \\
\hline Skor $<\bar{X}-0,5 \mathrm{~s}$ & Rendah \\
\hline $\bar{X}-0,5 \mathrm{~s} \leq$ skor $\leq \bar{X}+0,5 \mathrm{~s}$ & Sedang \\
\hline Skor $>\bar{X}+0,5 \mathrm{~s}$ & Tinggi \\
\hline
\end{tabular}

(Budiyono, 2009:52)

Proses pemilihan subjek selanjutnya dilakukan teknik snowball sampling. Teknik snowball sampling merupakan teknik penentuan subjek yang mula-mula jumlahnya sedikit, semakin lama berkembang semakin banyak. Dengan teknik ini, jumlah informan yang akan menjadi subjek akan terus bertambah sesuai kebutuhan dan terpenuhinya informasi (Sugiono, 2007). Langkah-langkah pemilihan subjek sebagai berikut: (1) subjek dipilih berdasarkan kriteria yang sudah ditentukan, (2) peneliti memberikan tes pemecahan masalah pecahan pertama pada siswa yang memiliki tingkat kemampuan awal matematika tinggi, (3) dipilih satu subjek, kemudian data dianalisis guna melihat karakteristik berpikir reflektifnya, (4) dipilih satu subjek lagi, kemudian dianalisis sehingga memperoleh karakteristik berpikir reflektif baru guna melengkapi karakteristik yang diberikan oleh satu subjek sebelumnya, (5) kemudian dipilih satu subjek lagi dan dianalisis apakah terdapat perbedaan dengan subjek sebelumnya. Apabila karakteristik berbeda, dipilih lagi satu subjek dan dianalisis karakteristiknya. Begitu seterusnya hingga tidak ditemukan lagi karakteristik yang berbeda dengan subjek sebelumnya.

Teknik pengumpulan data yang digunakan dalam penelitian ini yaitu wawancara berbasis tugas. Agar data informan terjamin kebenarannya, maka dilakukan teknik triangulasi waktu. Menurut Patton (dalam Moleong, 2012: 330) triangulasi waktu merupakan teknik perbandingan dan pengecekan balik derajat kepercayaan suatu informasi yang diperoleh melalui waktu yang berbeda. Adapun langkah-langkahnya sebagai berikut: (1) memilih siswa yang memenuhi kriteria sebagai subjek penelitian dengan berdasar pada hasil konsultasi peneliti dengan guru mata pelajaran matematika; (2) melakukan pengambilan data yang pertama dengan cara meminta siswa yang memenuhi kriteria untuk menyelesaikan tes tertulis masalah pecahan yang pertama; (3) menganalisis hasil tes pada pengambilan data pertama; (4) melakukan pengambilan data kedua, dengan tujuan untuk 
melihat validitas data pada pengambilan data pertama; (5) menganalisis hasil tes pada pengambilan data kedua; (6) membandingkan hasil pengambilan data pertama dengan hasil pengambilan data kedua dari masing-masing subjek penelitian; (7) apabila data hasil pertama dan kedua konsisten, maka data tersebut dinyatakan valid.

Teknik analisis data dalam penelitian dilakukan dengan cara: (1) menelaah seluruh data yang tersedia dari berbagai sumber, seperti dari hasil wawancara dan data tertulis, serta pengamatan yang sudah dituliskan dalam catatan lapangan, kemudian mereduksi data, yaitu dengan memilih hal-hal pokok yang sesuai dengan fokus penelitian; (2) menyajikan data dalam teks naratif; dan (3) menyimpulkan karakteristik berpikir reflektif berdasarkan masing-masing jenis kelamin berkemampuan awal matematika tinggi.

\section{PEMBAHASAN}

Berdasarkan hasil konsultasi peneliti dengan guru mata pelajaran matematika, didapatkan siswa yang memenuhi kriteria pemilihan subjek yaitu satu siswa laki-laki berkemampuana awal matematika tinggi dan dua siswa perempuan berkemampuan awal matematika tinggi. Selanjutnya melaksanakan pengambilan data proses berpikir reflektif siswa dengan menggunakan wawancara berbasis tugas pada tiga siswa tersebut. Kemudian peneliti menganalisis hasil tes pemecahan masalah yang pertama. Peneliti mewawancarai untuk mengklarifikasi jawaban yang diberikan subjek dengan berpedoman pada pedoman wawancara. Selanjutnya melakukan pengambilan data yang kedua. Hal ini dilakukan untuk melihat validitas data proses berpikir reflektif siswa dengan cara membandingkan hasil pengambilan data pertama dengan hasil pengambilan data kedua. Selanjutnya jika terdapat data yang berbeda maka akan direduksi. Sehingga data yang valid tersebut dapat disimpulkan menjadi hasil karakteristik berpikir reflektif siswa yang memiliki tingkat kemampuan awal matematika tinggi.

Berdasarkan hasil triangulasi waktu dalam penelitian ini, diperoleh hasil analisis karakteristik berpikir reflektif subjek dalam memecahkan masalah pecahan. Pada kemampuan awal matematika tinggi, hanya subjek perempuan saja yang mampu melakukan berpikir reflektif pada tahap memahami masalah. Adapun karakteristiknya yaitu menyebutkan informasi pada masalah, dan menjelaskan apa yang telah dilakukan. Hal yang berbeda terjadi pada subjek laki-laki yang tidak mampu melakukan berpikir reflektif pada tahap memahami masalah. Hal itu dikarenakan subjek laki-laki kurang mampu memahami masalah yang diberikan dengan memberikan informasi dan pertanyaan yang kurang lengkap. Selain itu, subjek laki-laki tidak menunjukkan perilaku yang mencerminkan sikap berpikir reflektif lainnya seperti hanya dapat menyebutkan apa yang diketahui dan yang ditanyakan tanpa menyadari informasi lain yang dibutukan untuk menjawab apa yang ditanyakan.

Dalam merencanakan penyelesaian masalah, subjek berkemampuan awal matematika tinggi melakukan berpikir reflektif yang sama dengan karakteristik 
mengidentifikasi konsep yang ada pada masalah, dan menjelaskan apa yang telah dilakukan.

Subjek laki-laki maupun perempuan berkemampuan awal matematika tinggi dapat melakukan berpikir reflektif pada tahap melaksanakan rencana penyelesaian masalah. Namun dalam tahap ini subjek laki-laki mampu berpikir reflektif lebih baik dibandingkan subjek perempuan. Hal ini ditunjukkan dengan karakteristik berpikir reflektif yang diperoleh yaitu menyadari kesalahan dan memperbaikinya, memeriksa kebenaran dari suatu argumen, menggunakan pengetahuan yang berasal dari dalam diri, mengaitkan informasi yang telah diketahui, dan mengkomunikasikan ide dengan simbol bukan dengan gambar atau objek langsung. Sedangkan subjek perempuan hanya mampu memiliki karakteristik berpikir reflektif menyadari kesalahan dan memperbaikinya, serta memeriksa kebenaran dari suatu argumen saja. Subjek perempuan tidak dapat membuat kaitan antara pengetahuan yang sudah diberikan dengan masalah yang dihadapi, tidak dapat membuat kaitan antara informasi yang sudah diperoleh guna menjawab pertanyaan, dan tidak dapat menjelaskan perhitungan yang telah dilakukan dengan yakin dan benar.

Subjek laki-laki berkemampuan awal matematika tinggi saja yang mampu melakukan berpikir reflektif pada tahap memeriksa kembali. Hal ini dibuktikan dengan karakteristik yang diperoleh yaitu menarik kesimpulan untuk mengembalikan ke dalam konteks masalah, dan menjelaskan apa yang telah dilakukan. Sedangkan subjek perempuan tidak mampu berpikir reflektif pada tahap memeriksa kembali. Hal itu dikarenakan subjek perempuan tidak mampu menarik kesimpulan untuk mengembalikan jawaban ke dalam konteks masalah.

Berdasarkan tahapan pemecahan masalah yang telah dilakukan oleh subjek penelitian, menunjukkan bahwa subjek laki-laki berkemampuan awal matematika tinggi yang dapat melakukan proses berpikir reflektif dengan baik pada tahapan pemecahan masalah. Hal ini didukung oleh Santrock (2007: 99), yang menyatakan bahwa anak lakilaki sedikit lebih baik dibanding dengan anak perempuan dalam matematika dan sains. Secara umum siswa laki-laki sama dengan siswa perempuan, akan tetapi siswa laki-laki memiliki daya abstraksi yang lebih baik dari siswa perempuan sehingga memungkinkan siswa laki-laki lebih baik dari pada siswa perempuan dalam bidang matematika, karena pada umumnya matematika berkenaan dengan pengertian yang abstrak.

Berdasarkan proses berpikir reflektif siswa SMP Negeri 3 Polanharjo Klaten yang sudah ditemukan, dapat disimpulkan bahwa siswa SMP Negeri 3 Polanharjo Klaten sudah mampu melakukan berpikir reflektif dengan baik. Hal ini sesuai dengan pendapat Hmelo \& Ferrari (1997) yang menyatakan bahwa siswa SMP sudah mampu melakukan ketrampilanketrampilan berpikir reflektif melalui dorongan mereka untuk: a) menghubungkan pengetahuan baru kepada pemahaman mereka yang terdahulu, b) berpikir dalam terminologi abstrak dan kongkrit, c) menerapkan strategi spesifik untuk tugas-tugas baru, dan d) memahami proses berpikir mereka sendiri dan belajar strategi. 
Terdapat beberapa kesamaan proses berpikir reflektif yang ditemukan di SMP Negeri 3 Polanharjo Klaten dengan teori Hmelo \& Ferrari (1997). Siswa SMP Negeri 3 Polanharjo Klaten sudah dapat menghubungkan pengetahuan baru kepada pemahaman mereka yang terdahulu ketika melaksanakan rencana penyelesaian masalah. Selain itu, siswa SMP Negeri 3 Polanharjo Klaten juga dapat menerapkan strategi spesifik untuk tugas-tugas baru pada tahap merencanakan penyelesaian masalah. Namun terdapat perbedaan hasil yang diperoleh dengan teori yang diajukan, yaitu siswa SMP Negeri 3 Polanharjo Klaten kurang dapat memahami proses berpikir mereka sendiri dan belajar strategi dalam pemecahan masalah. Hal ini ditunjukkan dengan hanya siswa laki-laki berkemampuan awal matematika tinggi saja yang mampu berpikir reflektif dengan baik pada tahapan pemecahan masalah. Selain itu, siswa hanya mampu berpikir dalam terminologi kongkrit. Peneliti berpendapat bahwa siswa SMP Negeri 3 Polanharjo Klaten akan merasa kesulitan dalam berpikir reflektif jika diberikan permasalahan yang abstrak. Dikatakan permasalahan yang abstrak karena permasalahan tersebut tidak nyata dan hanya dapat dibayangkan dalam pikiran saja. Misalnya masalah konsep pecahan yang menyangkut operasi pembagian yang tidak disajikan dalam bentuk soal cerita.

\section{SIMPULAN DAN SARAN}

Dalam penelitian ini dapat diketahui bahwa kemampuan awal matematika dan gender mempengaruhi berpikir reflektif siswa, sehingga dapat memperkecil faktor kesalahan ketika memecahkan masalah yang dihadapi. Hal tersebut dapat dibuktikan pada penelitian dalam pemecahan masalah pecahan. Hasil analisis karakteristik berpikir reflektif tersebut adalah sebagai berikut. (1) Siswa laki-laki berkemampuan awal tinggi: (a) tahap merencanakan penyelesaian, mengidentifikasi konsep pada masalah, menjelaskan apa yang telah dilakukan; (b) tahap melaksanakan rencana penyelesaian, menyadari kesalahan dan memperbaikinya, memeriksa kebenaran suatu argumen, menggunakan pengetahuan dari dalam diri, mengaitkan informasi yang telah diketahui, mengkomunikasikan ide dengan simbol bukan dengan gambar atau objek langsung; (c) tahap memeriksa kembali, menarik kesimpulan kekonteks masalah, menjelaskan apa yang telah dilakukan. (2) Siswa perempuan berkemampuan awal tinggi: (a) tahap memahami masalah, menyebutkan informasi pada masalah, menjelaskan apa yang telah dilakukan; (b) tahap merencanakan penyelesaian, mengidentifikasi konsep pada masalah, menjelaskan apa yang telah dilakukan; (c) tahap melaksanakan rencana penyelesaian, menyadari kesalahan dan memperbaikinya, memeriksa kebenaran suatu argumen.

Beberapa saran yang dapat disampaikan berdasarkan pada hasil penelitian yang sudah dilakukan adalah sebagai berikut. (1) Bagi peneliti lain: (a) perlu dilakukan penelitian ulang di sekolah lain yang memiliki karakteristik sekolah yang hampir sama dengan tempat penelitian. Selain itu dapat diteliti lebih lanjut pada siswa di sekolah lain dengan kategori yang sama yaitu pada tingkat kemampuan awal matematika tinggi, sedang, dan rendah. Hal ini bertujuan untuk melihat apakah sama atau tidak dengan temuan 
penelitian; (b) Dapat dianalisis lebih lanjut mengenai karakteristik berpikir reflektif pada pemecahan masalah materi pecahan atau materi lain yang mungkin lebih cocok digunakan untuk mengembangkan kemampuan berpikir reflektif siswa. (2) Bagi guru: (a) hendaknya memperhatikan kemampuan awal siswa dan gender dalam pelaksanaan pembelajaran matematika di sekolah. Hal ini bertujuan agar setiap siswa dengan latar belakang kemampuan awal dan jenis kelamin yang berbeda dapat menggunakan kemampuan berpikir reflektif dengan baik pada setiap tahapan pemecahan masalah; (b) Setelah mengetahui karakteristik berpikir reflektif dalam pemecahan masalah matematika siswa SMP, guru dapat menyiapkan model pembelajaran yang sesuai sehingga dapat mengembangkan kemampuan berpikir reflektif secara optimal; (c) Hendaknya guru sering mengajukan pertanyaan-pertanyaan yang dapat melatih siswa untuk berpikir reflektif.

\section{DAFTAR PUSTAKA}

Arends, Richarrd. (2008). Learning to Teach, Buku I. Yogyakarta: Pustaka Pelajar.

Budiyono. (2009). Statistika untuk Penelitian. Surakarta: Sebelas Maret University Press.

Choy, C.S \& Oo, P.S. (2012). Reflective Thinking And Teaching Practices: A Precursor For Incorporating Critical Thinking Into The Classroom?. International Journal of Instruction, vol. 5, no. 1, hal. 1308-1470.

Dindyal. (2005). Emphasis on Problem Solving in Mathematics Texbooks from Two Different Reform Movement. Johor baru malaysia: the mathematics educational into the $21^{\text {st }}$ century project university teknologi malaysia, reform, revolution and paradigm shifts in mathematics education, johor baru, malaysia, nov $25^{\text {th }}-\mathrm{dec} 1^{\text {st }}$ 2005.

Erman Suherman. (2003). Strategi Pembelajaran Matematika Kontemporer. Bandung: IMSTEP-JICA.

Gurol, A. (2011). Determining the reflective thinking skills of pre-service teachers in learning and teaching process. Energy Education Science and Technology Part B: Social and Educational Studies 2011, vol. 3, no. 3, hal. 387-402.

H. B. Sutopo. (2006). Metodologi Penelitian Kualitatif Edisi Kedua. Surakarta: Universitas Sebelas Maret.

Hepsi Nindiasari, Yaya Kusuma, Utari Sumarmo, dan Jozua Sabandar. (2014). Pendekatan Metakognitif untuk Meningkatkan Kemampuan Berpikir Reflektif Matematis Siswa SMA. Jurnal Ilmu Pendidikan dan Pengajaran, vol. 1, no. 1, hal. 80-90. 
Hery Suharna. (2012). Berpikir Reflektif (Reflective Thinking) Siswa SD Berkemampuan Matematika Tinggi dalam Pemahaman Masalah Pecahan. 385-386. Universitas Khairun Ternate Press, Ternate.

Hmelo, D., \& Ferrari, M. (1997). The problem-based learning tutorial: Cultivating higher order thinking skills. Journal for the Education of the Gifted, 20 (4), 401-422.

Jozua Sabandar. (2010). Berpikir Reflektif dalam Pembelajaran Matematika. Tersedia pada: file. upi. Edu / ai. Php ? dir...\% 20 MATEMATIKA/...Berpikir\%20Reflektif2. Diakses tanggal 15 April 2014.

Mahasneh, A. M. (2013). The relationship between Reflective Thinking and Learning Styles among Sample of Jordanian University Students. Journal of Education and Practice. vol. 4, no. 21, hal. 50-55.

Moleong, Lexy J. (2012). Metodologi Penelitian Kualitatif. Bandung. PT. Remaja Rosdakarya.

Moss, J. (2010). A Partnership in Induction and Mentoring: Noticing How we Improve Our Practice. Australian Journal of Teacher Education, vol. 35, issue. 7, hal. 43-53.

Muhammad Irfan. (2013). Proses Berpikir Siswa dalam Pemecahan Masalah Sistem Persamaan Linear Dua Variabel Ditinjau dari Math Anxiety dan Gender. Surakarta: Tesis PPs UNS. Tidak diterbitkan.

Pentatito G. (2008). Efektivitas Pendekatan Realistik dalam Menyelesaikan Soal Cerita dan Sikap terhadap Matematika Ditinjau dari Kemampuan Awal Siswa Kelas IV SD di Kecamatan Purworejo Kabupaten Purworejo. Surakarta: Tesis PPs UNS. Tidak diterbitkan.

Santrock, J. W. (2010). Psikologi Pendidikan Edisi Kedua. Jakarta: Kencana.

Santrock, J. W. (2007). Psikologi Pendidikan Edisi Kedua. Jakarta: Kencana.

Song, H.D., Koszalka, T. A., \& Grabowski, B. L. (2005). Learners' Perceptions of Design Factors Found in Problem-Based Learning (PBL) that Suport Reflective Thinking. Educational Resources Information Center. Vol 1, no. 2, hal. 217.

Sugiono. (2007). Statistika untuk Penelitian, Cetakan Keduabelas. Bandung: Alfabeta

Sugiono. (2012). Metode Penelitian Kualitatif dan $R \& D$. Bandung: Alfabeta.

Suparno P. (2010). Filsafat Konstruktivisme dalam Pendidikan. Yogyakarta: Kanisius. 
Fina Tri Wahyuni, Jurnal Pendidikan Matematika Vol 1 No 1 (2018) hal.39

Syamsul Yusuf. (2009). Psikologi Perkembangan Anak dan Remaja. Bandung : PT Remaja Rosdakarya. 